\title{
The role of a language teaching institute with- in the context of a university
}

\section{Leslie Proctor, Jannie Botha and Dawid H. van der Vyver}

The history and development of INTUS (the Institute for Language Teaching of the University of Stellenbosch) is sketched in broad terms. Certain definitions of the role and function of a university are given and the differences between a language teaching institute and language departments of a university are outlined. It is maintained that research, particularly applied research and development, is the main task of the institute. However, much of this research must be done outside the parent institution, and often with private funding, and therefore a close working relationship has to be established with the private sector. Research findings have to be made available and future researchers have to be trained. A comprehensive list of publications put out by INTUS forms the final part of the article.

Die geskiedenis en ontwikkeling van INTUS (Instituut vir Taalonderrig van die Universiteit van Stellenbosch) word in breë trekke geskets. Sekere definisies van die rol en funksies van ' $n$ universiteit word gegee en die verskille tussen ' $n$ taalonderriginstituut en taaldepartemente aan ' $n$ universiteit word in hooftrekke beskryf. Daar word aangevoer dat navorsing, veral toegepaste navorsing, en ontwikkeling die hooftake van hierdie instituut is. Baie van hierdie navorsing moet egter buite die moederinstansie gedoen word en dikwels met privaatfondse. Daarom moet daar' $n$ hegte werkverhouding met die privaatsektor opgebou word. Navorsingresultate moet beskikbaar gestel en toekomstige navorsers opgelei word. 'n Omvattende lys van INTUS-publikasies maak die finale deel van die artikel uit.

\section{Introduction}

When the University of Stellenbosch founded its Institute for Language Teaching (INTUS) in 1975, the primary motivation was the widely felt need for more effective language teaching in South Africa. The mission of the Institute, formulated in its constitution, was therefore defined as the furthering "of language teaching over a wide terrain".

When the Institute had to define its primary focal points, it became clear that improvement in the quality of language teaching and learning in education for blacks would have to appear very high on the priority list. This explains why as early as in 1975 and immediately after 16 June 1976 meetings took place with and proposals were submitted to the Regional Director (In Cape Town), the Director-General and the Deputy-Minister of the Department of Education and Training.

In 1979 a meeting of strategic importance for the development of the Institute took place at the University of the North under the Chairmanship of the late Prof William Kgware, then 
Rector and Vice-Chancellor of that University as well as a patron of INTUS. During this founding meeting which led to the establishment of the Interuniversity Committee for Language Teaching (in which at present six universities for predominantly black students are represented) it was unanimously agreed and decided that, should the group want to undertake significant work to improve the language teaching for blacks,

* a united endeavour would be essential

* the vicious circle with regard to insufficient language proficiency in education for blacks should be breached at primary school level

* thorough research into the needs and deficiencies with regard to English as a means of instruction in black primary education should be undertaken (a needs analysis)

* innovative approaches to language teaching, by means of which more could be taught and learned more effectively in a shorter period, should be seriously investigated.

The insights arrived at during this meeting irrevocably determined the important decisions and the direction taken since those decisive first years of the Institute's existence. They started a chain of events, most of which had to do, directly or indirectly, with improved education for blacks in Southern Africa. Detailed descriptions and discussions of some of the most significant projects and actions undertaken are given by van der Vyver and Botha (1989).

The Institute for Language Teaching is one of several research institutes at the University of Stellenbosch. To warrant its position as a research institute, it needs, firstly, to justify its role in the broad context of a university, and, secondly, as an institute for language teaching, it needs to fulfil its function in the multilingual society of Southern Africa.

\section{Role and function of a university}

Various answers have been suggested, at different times and in different places, to the question as to the role and function of a university. One generally accepted answer is that a university has a two-fold task - teaching and research, or put in more refined terms, that a university exists in order to preserve existing knowledge, for example through its library and the expertise of its academic staff, to discover new knowledge, techniques, procedures and skills through its research activities and to pass on to its students existing and newly discovered knowledge, techniques and skills through its teaching programmes. The van Wyk de Vries Commission (1974) elaborated somewhat on this rather simplistic answer by maintaining that the function of a university was to advance learning, to educate and mould, to provide professional training and to instil in students common standards of good citizenship. Behr (1980) says: "However, this function must be seen in terms of the national context. The university is not a supra-national institution that can dissociate itself from the 
State, the community in which it is situated, and the larger society". Sir James Mountford, in his "British Universities" (1966) advocates a much broader function of a university. "It must necessarily provide the student with a body of positive knowledge which enhances his store of learning and in part equips him for his career in later life. But it also has another and more notable attribute. It inculcates in the student an attitude of mind which regards the critical assessment of facts and values as more important than dogmas, and which holds that a grasp of underlying principles is more valuable than the accumulation of information or the acquisition of skills and techniques. A university expects that at the end of their courses its students will not merely be able to comprehend the extent and significance of what is already known within their own field, but will be receptive to what is new, eager to explore it, show the ability to cope with it and - above all - be able to work confidently on their own..."

A strong sociological bias can be detected in the answer proposed by the United States Carnegie Commission on Higher Education: "to enhance the personal development of the student, to enhance human capability in society at large, to increase social justice through greater equality of opportunity for individuals to obtain the benefits of an advanced education, to advance learning for its own sake through science, scholarship and the creative arts, and to evaluate society for the benefit of its own renewal. It is no longer sufficient to say that higher education has the purposes of 'teaching, research and service'. Teaching to what ends? Research for what reasons? Service to whom? Attention now needs to move more toward the net social product and its enhancement through advancing human capability." (Focus, USAIS 1973). A completely different direction can be noted in A.N. Whitehead's essay, "Universities and Their Function" written in 1929: "The universities are schools of education and schools of research. But the primary reason for their existence is not to be found either in the mere knowledge conveyed to the students or in the mere opportunities for research afforded to members of the faculty...

"The justification for a university is that it preserves the connection between knowledge and the zest of life, by uniting the young and the old in the imaginative consideration of learning. The university imparts information, but it imparts it imaginatively ... This atmosphere of excitement, arising from imaginative consideration transforms knowledge. A fact is no longer a bare fact; it is invested with all its possibilities. It is no longer a burden on the memory: it is energising as the poet of our dreams, and as the architect of our purposes."

\section{Why does a university exist?}

Inherent in these quotations is a further question: Does a university exist to serve merely the community in which it finds itself and within the constraints and demands of the entity which spawned it, be it state, government, religious or commercial? The strains and stresses which arise and have, for centuries, arisen through an apparent incompatability between university authorities and/or students and the institution which helps to finance it, particularly in the eyes of the taxpayer, underline this point. Again, the answer to this question must be a twofold one. On one hand, a university, by definition, is a member of a world-wide community of teachers, scholars and researchers and has to ensure its continuing membership of that academic community by maintaining academic standards which are internationally acceptable. This means that it must strive to keep a broad vision; it must not serve, or be seen to serve, one 
particular group exclusively, nor must it subscribe to one particular ideology or philosophy, as did the University of Cambridge until the Eighteen Seventies, prior to which time no student was admitted unless he was a member of the Church of England, and as do most universities in Eastern Europe, Communist China and Russia today; it must resist all attempts to be circumscribed by a particular power group, as is the case with some of the non-Ivy League universities in the United States. On the other hand, a university exists in a particular place and at a particular time and must therefore take account of, in its teaching, research and service functions, the unique set of circumstances and needs of its own environment.

Every university in the developing countries of Africa is faced with crucial questions of such things as syllabi, curricula, and even the very language of the medium of instruction. Whereas the medieval universities could easily rely on using Latin as the lingua franca, thus enabling students to move easily from one university to another through Europe, students in today's African universities are faced with the problem, to many of them insuperable, of mastering English to enable them to carry out their function as students.

A healthy balance must therefore be maintained between the universal character of a university and its uniqueness, a situation which many students regard with suspicion, since they question the relevance of much of what they are doing.

\section{Research institutes in a university}

When an institute such as a language teaching institute first comes into being, or even when the possibility of its being founded is first mooted, this duality of the nature and role of a university must be reckoned with. The introduction of a new degree, department, faculty or institute must take place against the background of deep deliberation and sensible decisionmaking (at whatever level - Faculty, Senate, Council) in terms of, firstly the role and function of the university and then of the institute. So this duality, while not excluding university teachers (and some academics may jib at the use of the word "teacher") from carrying out research (no self-respecting academic can survive without a research programme), nor its researchers from teaching (although not all researchers are interested in or "good" at teaching) does mean that research institutes, because of their structure, financing and resources are often better able to carry out research, particularly on a co-operative basis inside or outside the university, than their faculty or departmental counterparts.

When the head of an institute is first appointed, he must give intense thought and expression as to the nature of his institute and the direction which he wishes it to take. His decisions may not meet with universal approval from fellow academics, or even from university authorities, but within the context of academic freedom, he should be given the freedom and authority to develop the institute as he sees fit - if he is unable to do this, then there was something wrong with the original appointment. Further, every decade or so, the head of an institute, in collaboration particularly with his members of staff, should do some navel-contemplating by looking back on what the institute has achieved over the years and what he hopes to achieve, assuming that he is still in office, over the next ten years. 


\section{Institute for Language Teaching}

The Institute for Language Teaching of the University of Stellenbosch has been in existence for just over a decade, and it is appropriate at this point in its history to carry out a selfexamination, both for its own health and for the benefit of fellow academics. But, before any detailed examination is attempted, it is important to reiterate some generalisations, and the primacy of language as a human phenomenon is a good starting point. Whether it be natural language, the language of computer programming, or the imaginative language of art and music, language plays a central role in man as a thinking and feeling being. Thought, emotion, discussion, argument, the development of attitudes and feelings (the "zest of life" mentioned by Whitehead earlier) cannot take place without language, or at least against the background of language, and this is even more true in a university environment. Many of the difficulties encountered by students, particularly in their first year, are attributable to deficiencies in their language, even or especially in their mother tongue. Post-graduate students, with the possible exception of those in language departments, find the writing of research reports the most difficult part of their research endeavours.

\section{Difference between an institute for language teaching and a language department}

If we accept this axiom of the supremacy of language as an activity or process, the question arises as to the precise function of an institute vis-á-vis other departments in the humanities. Teaching of and research into the nature, use and function of a specific language may be said to be the province of language departments, particularly language in its literary forms. Research into language teaching, language acquisition and language learning, and possibly the teaching of these topics, should be the major thrust of an institute such as INTUS. Courses in the methodology of teaching a specific language (teacher training) belong properly to a Faculty of Education. Both pure and applied linguistics are concerned with language universals, rather than with aspects of a specific language.

If the points made in the previous paragraph suggest a pigeon-hole approach, a syndrome found particularly in high schools, where pupils are led to believe that a particular subject on the time-table has nothing to do with the subject in the next period, or where the language being studied can be divided into separated and unrelated activities and therefore separate slots in the time-table (language, spelling, reading, set-works, composition, and so on), one would reply by arguing for an inter-disciplinary approach (topics such as "Language in Education"), where members of a faculty or even of faculties, would contribute, on a cooperative basis, their particular expertise. The traditional division of research into "basic" and "applied" - a division commonly found in the natural sciences - is not really sharp enough for the humanities. The official Research Policy (Navorsingsbeleid) of the University of Stellenbosch recognises this inadequacy and goes further than this simple division and states: "Die interpretasie van die begrip navorsing deur dosente in verskillende vakgebiede verskil soms grootliks. Ter wille van 'n sinvolle gemeenskaplike vertrekpunt en 'n betroubare verwysingsraamwerk vir verdere bespreking in 'n dokument soos hierdie, is dit nodig dat daar vooraf ooreengekom moet word oor wat met navorsing bedoel word. Omdat die Universiteit dit reeds so goedgekeur het, word die omskrywing van navorsing soos wat dit 
in artikel 8 van die Universiteit se Navorsingsbeleid voorkom, hier aanvaar, naamlik: Navorsing behels alle pogings om, aan die hand van duidelik geformuleerde probleme en deur metodiese insameling en sistematiese verwerking van gegewens, insigte te verwerf waardeur (1) die liggaam van basiese wetenskaplike kennis uitgebrei kan word (2) die toepassingsmoontlikhede van teoretiese kennis wetenskaplik ontgin kan word; en (3) tegnieke, stelsels, prosesse of middele vir praktiese gebruik op 'n wetenskaplik beplande en gefundeerde wyse ontwikkel of verbeter kan word. Hierdie beskrywing sluit dus basiese navorsing, toegepaste navorsing en ontwikkeling in" (1987, p.2).

This further refinement of the term research, as outlined in the above document, is necessary in order to understand the complexity and comprehensiveness of research into language teaching.

It is our contention that the second and third divisions of the above definition of research (viz applied research and developmental research) should receive the major emphasis in an institute such as INTUS. In the field of language teaching and learning, there are not many Chomskys, Piagets, Skinners or Lozanovs, and their discoveries through their research are not everyday events. On the other hand, research into the application, extension, limitations or development of the research of such giants is valid, frequent and worth while, either against the background of "universalia" or within a particular language teaching framework or context.

Furthermore, research of this second and third kind - applied research and developmental research - cannot normally take place or be successful without guinea pigs. It is in this respect that an institute for language teaching cannot do otherwise than offer what are termed "service courses" - not necessarily to its own students, as it may not have many, or indeed any at all, but to students either from within the university (other language departments) or from outside the university. For example, research into the effectiveness or limitations of computer-based instruction cannot take place without a computer and students sitting and working at the computer. By the same token, research into the effectiveness or limitations of certain methods or techniques used by black primary school teachers in standard three cannot take place without black primary school teachers and standard three children. Thus, service courses, especially when followed up by research reports are an integral part of the research strategy and process and without them research of that kind is impossible. It may even be that one presentation of a service course is insufficient in the sense that further courses with the same subjects may modify or even negate the research findings. One further point is that developmental work such as service courses are free from traditional constraints such as examinations and syllabi, which tend to straitjacket or stereotype the teaching of languages at school or university.

As indicated in the Research Policy (Navorsingsbeleid), cerlain steps are necessary in order to carry out research, especially applied and developmental research, Firstly it is essential to carry out a literature search to ascertain the state of the art, to describe the existing situation. This first step is time-consuming and dependent on access to journals and books. In this respect INTUS is fortunate, as it has its own library with a wide range of journals constantly updated, as well as access to the University Library and through it to the interlibrary loan system. A literature search will also entail a study of research already conducted by other individuals or groups into the topic to be researched. This study will naturally 
influence decisions on the research to be pursued - whether it is worth while re-inventing the wheel, whether the wheel needs modification or whether it is indeed obsolete.

The question naturally arises as to who is to do all this reading. The answer provides a clue to an important aspect of research in an institute - the co-operative nature of the venture. Whereas a researcher working towards a higher degree is largely on his own, apart from his promoter ("the loneliness of the long-distance researcher"), research in an institute will usually be a joint venture (teamwork), with various roles being allocated to various members of staif. The assistance of outside individuals or groups may also be solicited, especially where such expertise is not normally found within the institute, for example in the statistical aspects of the project. Every research project undertaken by INTUS has a project committee, whose responsibility it is to exercise general supervision over the project and the researchers. There is also a project leader, who decides on such matters as role allocation.

Language teaching is a process, and processes are, by definition, continuing and changing. It is a well-known educational principle that no two groups of learners are alike, in fact no two learners are identical - they differ in degree and kind of motivation, leaming styles and speed, and many other factors. By the same token, the same group of learners changes from day to day, with subtle influences and interchanges causing the kaleidoscope to change its configurations. This process is a two-way traffic - there is a provider of the services (some people would prefer the word "facilitator") - the teacher or the researcher and there is a consumer - the student. The process will not operate successfully if the needs of the consumer have not been established and taken account of. Both the perceived and felt needs of the consumer are established by means of a needs analysis, which is an indispensable next step in the research procedure. If the needs of the learner are not established, the specification of a syllabus or decisions about methodology will be futile. Two needs analyses recently carried out by INTUS are worthy of mention and may be regarded as models of their kind. They are to be found in Per Linguam, Special Issue No.1 of 1985 and Special Issue No.3 of 1988.

In Special Issue No.1, Dr M. S. Odendaal reported on a needs analysis of higher primary teachers in KwaZulu. Whereas various researchers and writers both in South Africa and overseas had concerned themselves with the state of English either as a subject or as a medium of instruction, Dr Odendaal focused specially on the language needs (specifically English) of black primary teachers in KwaZulu by means of empirical data obtained from questionnaires, observation and interviews. The proficiency in English of the sample studied was established by means of the General Advanced Test, devised by Brendon Carroll for testing communicative performance. Dr Odendaal concluded that the respondents' proficiency in English was inadequate for the task they had to perform. The average was band 6, while the target for teachers was band 8 .

Special Issue No.3 of 1988 was entitled Afrikaans for Transkei. Shortly after Transkei gained its independence in 1976, Afrikaans was abolished as a compulsory school subject. However, the authorities soon realised that a knowledge of Afrikaans was important for better work opportunities, especially in South Africa. Consequently it was re-introduced as an optional subject and the Transkei Education Department approached INTUS to carry out a survey of the needs of teachers so as to improve the teaching of the subject at school and training college level. 
Such a survey, the first of its kind, was carried out by Mrs N. Rousseau, who drew up detailed questionnaires and carried out interviews with college lecturers, students, teachers and senior officials in the Department. The survey indicated that few teachers in Transkei were proficient enough for the task of teaching the language and identified the crux of the problem as the need to upgrade the proficiency of the Afrikaans of teachers and teacher trainees. The outcome of the survey was a communicative syllabus for teacher trainees at training colleges.

\section{Aspects of research into language learning and teaching}

The major step in a research procedure is the evaluation of techniques, procedures or methods, or the solving of problems in language teaching. Both evaluation and problem solving must take place within a general as well as a specific framework. This means that although a technique or method of language learning or teaching has been found to be effective elsewhere or under other conditions, or a solution has been shown to be effective for a problem posed wihtin a different set of circumstances, there is no guarantee that the solutions will apply to the kinds of problems to which INTUS may address itself. For instance, the solutions proposed to certain problem areas in the teaching of English of KwaZulu primary school teachers. By the same token improvements in the teaching of Afrikaans in the Transkei are not identical to those suggested for the improvement of the English of those KwaZulu teachers.

No research is possible in language teaching without using live students, as was suggested earlier. Problem solving or summative evaluation of course materials or methods can only take place in a real teaching-learning situation. This does not necessarily mean that the researcher must do the teaching himself, but it does mean that (s)he must have experience of language teaching and must have achieved demonstrable success in teaching. This axiom leads to two important considerations. Firstly, INTUS must offer courses which may officially be regarded as service courses. Secondly, most of the research undertaken will have to be done outside the university, usually with external funding.

In these respects an institute differs vastly from the traditional academic department, whose activities are largely confined to its own campus and invariably to its own (registered) students. The department offers qualifying courses for a degree within its own institution. It also receives funding for its teaching function from within the university. An institute, on the other hand, will often operate (teach) in the field; the courses it offers in order to execute its research function will be non-qualifying, sometimes at a level far removed from the usual university standard. It will receive funding for a project from outside sources, and if the project is a long-term one, the financial support can be expected to be looked at with envy by academic departments who have to inure themselves to perennial cuts in financing and staffing. For a large project an institute may appoint extra (temporary) staff, which again may be looked at with a jaundiced eye by other departments who perennially regard themselves (often with justification) as being understaffed.

Another aspect of research into language teaching and learning is the time scale involved. The length of time taken from the statement of the problem, the posing of the hypothesis, the 
execution of the experiment and the reporting of the research results will depend on the nature of the problem, but one should be aware of the dangers of "crash" courses and the consequent Hawthorne effect. There is no such thing as instant learning. Consequently, research is timeconsuming. A twenty-six part television programme, for instance, beamed at weekly intervals will take longer than six months as a research project: the time required for initial research (needs analysis), the writing of the scripts, the recording of the programme and the analysis of results will mean that the time scale is far greater than most people (including fellow academics) would expect.

Here we would refer specifically to a research project undertaken by DrW.E. Trengove, entitled "That man from London". This entitled the writing of the script of a 26-part TV programme intended for black viewers, and research into the effectiveness of television as a medium for language teaching. One of the important aspects of teaching by television in an informal situation (that is without a formal teaching situation, where a teacher can evaluate the students' progress) is the logistical and procedural problem of evaluation. One cannot obviously apply a formal test to $x$ thousand TV viewers, many of whom may, in any event, not have watched on a regular or intensive basis. It would be possible, by means of questionnaires and sample interviews to establish the affective results of the programme series. But probably the only way of evaluating the cognitive outcomes of the programme would be to seek the collaboration of a large industrial concern, get them to identify those of their workers who had in fact been viewing the programme, and apply a test in a controlled situation. Not all employers, however, are prepared to go to these lengths of allowing their employees time off for such purposes.

This underlines an important point about an institute - it is essential to develop sound and friendly relations with commerce and industry, who are able to provide facilities by making subjects available for interviews and questionnaires.

Such was indeed the case with the research reported in Special Issue No.2 of 1987, Language training in industry, with special reference to the Cape Town metropolitan area by Gxilishe and van der Vyver. The research covered industries in the Cape Peninsula, but most of the language problems highlighted and solutions offered in the report are applicable to similar labour situations elsewhere. The findings were based on a survey of the literature, a questionnaire to a sample of 120 industries, interviews with the personnel management of 16 of these industries and interviews with a sample of 56 black workers. Without the cooperation of these 120 companies, no research of this nature would have been possible.

\section{Balanced research}

One of the dangers which an institute has to face is that of developing perceptions among outsiders of "bandwagonism". An institute has to guard against giving the impression that it is all for a particular theory, method or fashion, and is entirely against another. How to present research findings in a balanced and objective manner without seeming to favour or to reject one theory or practice is a dilemma which is not easily solved. Mark A. Clarke, in his On Bandwagons, Tyranny and Commonsense. (TEFL QUARTERLY Dec. 1982) distinguishes between a methodological trend and a bandwagon which poses a simple answer to a complex problem and which advocates a "complete revocation of what has gone before", in the belief 
that success in language teaching" in addition to adherence to a prescribed body of knowledge and beliefs, is dependent on the use of particular paraphernalia and techniques".

But whatever the results of research, even that which proclaims "no significant difference", those results should be made known to the academic world through publication.

\section{Publication of research findings}

From 1976 to 1984, the activities were reported and articles and research reports of INTUS were published in INTUSNews and elsewhere. However, it was felt that a more academic type of journal was required for INTUS, with facilities for longer articles, and so Per Linguam came into being in 1985 and has recently been recognised by the Department of National Education for subsidy purposes. In the Editorial of the first issue it was stated that "the main concern and focal point of Per Linguam will be language and communication in Southern Africa in an attempt to improve relations between, and the quality of life of, all its people ...Per Linguam wants to provide a forum for the discussion of new developments and techniques in language teaching by specialists, in the hope that (it) may become a unifying force towards better communication and better understanding in this part of Africa." These aims are still valid today.

INTUS, although emanating from a university whose main medium of instruction is Afrikaans, and whose students are on the whole Afrikaans speaking, has never limited itself to the study of Afrikaans or the use of Afrikaans as its publication medium. A great deal of attention has been paid, in both research and publications, to African languages, more particularly Xhosa, as this is the African language found predominantly in the Western Cape. Since Xhosa is the language taught in white schools in the Cape Province, INTUS has published on a regular basis its Xhosa Newsletter, which was intended mainly for teachers of the language.

A major research project into the teaching of Xhosa was that undertaken by Gxilishe, which eventually led to the award of the D.Litt degree at the University of Stellenbosch, the first time that a black candidate had been awarded a Doctorate at the University. The title of the thesis was "Oral Proficiency in Xhosa as a second language". A summary of the research findings was published in Per Linguam, Vol.3 No.2, 1987. The construction and administering of an oral proficiency test in Xhosa showed to what extent the aims of the Xhosa syllabus for the Senior Certificate examination were met, taking into account the two main (stated) objectives of the syllabus - to develop the listening and speaking skills of the pupils and to use the communication means in everyday situations. The emphasis of the test items in the research project was not on linguistic accuracy but on the pupils' ability to function effectively through language in particular settings and contexts. The validity, reliability and practicability of the test as well as its administration were reported.

\section{A need for training researchers}

One of the less commonly acknowledged functions of an institute is that of training future researchers. Such people may have carried out research on a limited scale as part of their degree requirements, but if they are to make a career primarily in research, for example in an 
institute, they must become involved from the outset of their appointment in research. Potential researchers may be full-time appointees, or contract staff appointed to this end; they should receive guidance and training in research techniques, and they can expect to work in an atmosphere where originality and imagination are encouraged, which, after all, are the hall-marks of good research. A recent report in the Economist (21.1.87) underlines the need for better training of researchers. The (British) Economic and Social Research Council "would prefer to see more systematic teaching of research skills and fewer unrealistic expectations placed on young men and women who are undertaking their first piece of serious research. So in future, its grants will be given only where it is convinced that students are being trained as researchers, rather than carrying out purely knowledge-based studies."

The real worth of an institute can only be measured by its standing in the national and international community of scholars. The publications of a research institute are the lifeline to the academic community in which it is embedded and to the society which it serves. Sever it and the function of the institute becomes null and void. The last section of this article which contains a list of publications, reports and dissertations speaks for itself.

\section{Bibliography}

BEHR, A.L. 1980. Teaching and learning at university. Durban: Butterworth.

CARNEGIE COMMISSION ON HIGHER EDUCATION, 1973. Washington: FOCUS, Usais.

CLARKE, M.A. 1982. On bandwagons, tyranny, and common sense. TEFL Quarterly, Vol.16(4).

ECONOMIST, London: 21.1.87.

GXILISHE, D.S. 1987. Oral proficiency in Xhosa as a second language. Stellenbosch: Per Linguam, Vol.3(2).

GXILISHE, D.S. and D.H. van der Vyver. 1987. Language training in industry with special reference to the Cape Town metropolitan area (Area 39). Stellenbosch: Per Linguam, Special Issue No.2.

MOUNTFORD, J. 1966. British universities. Oxford: Oxford University Press.

ODENDAAL, M.S. 1985. Needs analysis of higher primary teachers in KwaZulu. Stellenbosch: Per Linguam, Special Issue No.1.

ROUSSEAU, N. 1988. Afrikaans for Transkei. Stellenbosch: Per Linguam, Special Issue No.3. 
UNIVERSITY OF STELLENBOSCH. 1987-1991. Navorsing Aksieplan.

VAN DER VYVER, DAWID H. and H. LUDOLPH BOTHA. 1989. The implementation and evaluation of Suggestopedic/SALT Research project submitted to HSRC. Institute for Language Teaching: University of Stellenbosch.

VAN WYK DE VRIES COMMISSION. 1974. Commission of enquiry into universities. Pretoria: Government Printer.

WHITEHEAD, A.N. 1950. The aims of education and other essays. London: Ernest Benn. 
INSTITUTE FOR LANGUAGE TEACHING

Publications/Reports/Dissertations for the period 1976 - 1989

(* = Published in Afrikaans)

1 Regular publications of the Institute

INTUSNEWS (Since 1977, edited by VAN DER VYVER, D.H. - 14 numbers; in 1984 edited by BOTHA, J.J. - 3 numbers)

PER LINGUAM (since 1985, edited by VAN DER VYVER, D.H. - 9 regular numbers; 3 special numbers)

XHOSA NEWSLETTER (since 1978, edited by BOTHA, J.J.; GXILISHE, D.S. - 21 numbers)

\section{Publications by staff attached to the Institute}

\section{5-1979}

Except for numbers of INTUS News and 4 numbers of Xhosa Newsletter, no other publications.

\section{0}

BOTHA, J.J. 1980. Computer-based education and ESP. Journal for Language Teaching 15(3), 2-10.

BOTHA, J.J. 1980. Reading comprehension and science texts. INTUS News 5(1), 12-20.

BOTHA, J.J. 1980. Teaching Bantu languages for special purposes. The Linguistic Reporter 23(6), 7-10.

ODENDAAL, M.S. 1980. Constraints on the design of a PLATO course for foreign language learners. Journal for Language Teaching 15(3), 11-23.

\section{1}

BOTHA, J.J. 1981. The need for communicative LSP in a multilingual society. Proceedings of the 3rd European Symposium on LSP. Copenhagen: Copenhagen School of Economics, 267-281.

GXILISHE, D.S. 1981. Developing a Xhosa syllabus for medical students. Stellenbosch Studies in African Languages 1, 115-146. 
VAN DER VYVER, D.H. 1981. Aims of teaching a third language in South African industry.* Working Committee Report: Languages and Language Teaching, HSRC, 113-116.

VAN DER VYVER, D.H. et al. 1981. Evaluating and examining in language teaching at primary and tertiary level and in industry.* Working Committee Report: Languages and Language Teaching, HSRC. 177-182.

\section{2}

BOTHA, J.J. 1982. Computer-based education and EST - report on a project in progress. SYSTEM 10(3), 277-284.

BOTHA, J.J. 1982. Computer-managed instruction with special reference to second language teaching. Stellenbosch: Proceedings of SACCE 82: Computers in Education, 379-401.

BOTHA, J.J. 1982. Reading comprehension and science texts. Communique 8(1), 12-22.

GXILISHE, D.S. 1982. On certain aspects of the Xhosa culture.* Xhosa Newsletter 5(2), 1314.

GXILISHE, D.S. 1982. Progress report on the Basic Xhosa Course for Industry. INTUS News $6(1), 4$.

GXILISHE, D.S, G. Kroes and D.H. van der Vyver. 1982. Forms of address and reference - abbreviated report.* INTUS News 6(1), 6-10.

ODENDAAL, M.S. 1982. Second language learning and computer-assisted language instruction (CALI). Stellenbosch: Proceedings of SACCE 82: Computers in Education, 499-509.

VAN DER VYVER, D.H. (Ed.) 1982. Computers in Education / Rekenaars in die Onderrig. Stellenbosch: SACCE 82 (533 pages).

\section{3}

ANNAS, R., L. de Stadler, E. Ridge and D.H. van der Vyver. 1983. Error analysis project: Research report.* INTUS News 7(1), 11-17.

BOTHA, J.J. 1983. The need for language training in ESCOM. Johannesburg: ESCOM (confidential report).

BOTHA, J.J. 1983. Steps in lesson design for computer-based instruction 1.* Die Unie 79(12), 321-322. 
BOTHA, J.J. 1983. Steps in lesson design for computer-based instruction II.* Die Unie 80(1), 19-20.

BOTHA, J.J. and L. Proctor. 1983. English for Science Students in South Africa. Stellenbosch: Institute for Language Teaching. Design document for PLATO project.

ENGELBRECHT, J.T. and D.S. Gxilishe. 1983.Xhosa for Industry. Cape Town: Via Afrika. (171 pages).

ENGELBRECHT, J.T. and D.S. Gxilishe. 1983. Zulu for Industry. Completed, not published.

ENGELBRECHT, J.T. and D.S. Gxilishe. 1983. Sotho for Industry. Completed, not published.

ODENDAAL, M.S. 1983. Foundations in English for industry. Stellenbosch: Institute for Language Teaching. Design document for PLATO project.

\section{4}

BOTHA, J.J. 1984. A PLATO-based English for ScienceProject. ADCIS Proceedings 1984. INTUS News 8(2), 49-52.

BOTHA, J.J. 1984. The role of the computer in school I.* Die Unie. 80(7), 208-209.

BOTHA, J.J. 1984. The role of the computer in school II.* Die Unie 80(8), 269-270.

BOTHA, J.J. 1984. The role of the computer in school III.* Die Unie 80(9), 309-310.

BOTHA, J.J. 1984. Teaching techniques in computer-based language instruction.* INTUS News 8(1), 49-53.

\section{5}

BOTHA, H.L. 1985. An analysis of SALT in practice. Per Linguam 1(1), 7-9. Research design report.*

BOTHA, H.L. 1985. Suggestopedia in the classroom with reference to similar principles in other language teaching approaches. ${ }^{*}$ Journal for Language Teaching 19(9), 6370 .

BOTHA, J.J. 1985. Computers and the writing process. Per Linguam 1(1), 34-37. 
GXILISHE, D.S. 1985. The Natural Approach: Language acquisition in the classroom - a review article. Per Linguam 1(2), 51.

ODENDAAL, M.S. 1985. Needs analysis of higher primary school teachers in KwaZulu. Per Linguam, Special Issue 1, 5-99.

TRENGOVE, W.E. 1985. That man from London. Scripts for SABC TV: 26 episodes $\times 20$ minutes each. Televised on TV2/3, 1987.

VAN DER VYVER, D.H. 1985. SALT in South Africa: needs and parameters. Per Linguam $1(1), 3-6$.

VAN DER VYVER, D.H. 1985. Suggestopedia/SALT: Introduction to the theory and a review of the history with special reference to Southern Africa.* Journal for Language Teaching 19(9), 27-48.

VAN DER VYVER, D.H. 1985. Suggestopedia. 4 x 15 minutes scripts for SABC TV.

\section{6}

BOTHA, J.J. 1986. The teaching of reading in a second or foreign language - some viewpoints.* Xhosa Newsletter 9(1), 8-13.

BOTHA, J.J. 1986. Using microcomputers in second and foreign language instruction. Research report, (73 pages); Addendum (156 pages). [Published by author.]

GXILISHE, D.S. 1986. Creative story telling. Xhosa Newsletter 8(2). 6-7.

GXILISHE, D.S. and M. Pughe-Parry. 1986. The use of picture stories in teaching an intsomi. Xhosa Newsletter 9(1), 44-46.

ODENDAAL, M.S. 1986. Upgrading of English for black primary school teachers constraints analysis* [Confidential report.]

VAN DER VYVER, D.H. 1986. The teaching of English to black TV viewers by means of the suggestopedic approach.* RTV 1(2), 53-64.

\section{7}

BOTHA, H.L. 1987. Suggestopaedia: theory and application in teachers' colleges. The NESLATT Journal 2, 6-17.

BOTHA, J.J. 1987. Computers in language teaching.* Per Linguam 3(1), 14-19.

BOTHA, J.J. 1987. Strategies for the teaching of reading in a second language. Xhosa Newsletter 10(1), 4-6. 
GXILISHE, D.S. 1987. A Xhosa communicative test for senior L2 pupils. Per Linguam 3(2), 3-21.

GXILISHE, D.S. 1987. Oral proficiency in Xhosa. Xhosa Newsletter 9(2), 6-9.

GXILISHE, D.S. and D.H. van der Vyver. 1987. Language training in industry with special reference to the Cape Town metropolitan area (Area 39). Per Linguam, Special Issue No.2, 1-63.

ODENDAAL, M.S. 1987. Raising achievement levels by means of Suggestopedia. Per Linguam 3(2), 22-30.

ROUSSEAU, N. and M.S. Odendaal. 1987. Designing an Afrikaans (third language) communicative syllabus. Per Linguam 3(2), 39-45.

VAN DER VYVER, D.H. 1987. English and operacy for teachers. Per Linguam 3(1), 1-4.

\section{8}

BOTHA, J.J. 1988. Communicative approaches in computer-assisted language instruction. Per Linguam 4(1), 44-50.

BOTHA, J.J. 1988. Computers and language teaching techniques: integration or segregation?* Journal for Language Teaching 22(2), 9-21.

BOTHA, J.J. 1988. Runaway technology: implications for computer-assisted language learning (CALL). S.A. Journal of Education (accepted for publication in second issue 1989).

BOTHA, J.J. 1988. CALL in the Republic of South Africa. JUNG, U.O.H. (Ed.) 1988. Computers in applied linguistics and language teaching. Frankfurt: Peter Lang. 349-353.

GXILISHE, D.S. 1988. An analysis of four variables in a Xhosa communicative test for L2 pupils. Per Linguam 4(1), 2-15.

ROUSSEAU, N. 1988. Afrikaans for Transkei. Per Linguam, Special Issue No.3, 7-91.

VAN DER VYVER, D.H. 1988. Language teaching in South Africa: stifling or releasing?* Erasmus, G.F. (Ed.) Afrikaans: Horisonne en ideale. Paarl: Afrikaans Language Fund. 73-82. 


\section{9}

BOTHA, H.L. Tweedetaalteorie vir die eerstetaalonderwyser. Per Linguam (5)1, 50-58.

BOTHA, J.J. Die rol van die rekenaar by mondeling. Per Linguam (5)1, 42-49.

PUHL, C.A. and J.J. Swartz. Designing a second language bridging course for university students. Per Linguam (5)1, 17-32.

VAN DER VYVER, D.H. and B. Capdevielle. Towards the mountain: characteristics and implications of the South Arican UPTTRAIL pilot project. Per Linguam (5)1,916.

3 Dissertations and theses (in collaboration with other departments at the University of Stellenbosch)

\section{1}

VORSTER, D.J. 1981. The teaching of Xhosa in the primary school.* (M.A.). Supervisors: J.J. Botha and J.A. du Plessis (258 pages).

\section{5}

ODENDAAL, M.S. 1985. The application of Munby's taxonomy of language skills for the design of a communicative course in English for teacher trainees in KwaZulu. (D.Ed.) Promoters: J.J. Botha and W.E. Trengove (300 pages).

\section{6}

BOTHA, H.L. 1986. Suggestopaedia for second language acquisition. (D.Ed.) Promoters: D.H. van der Vyver and W.E. Trengove (462 pages).

\section{7}

GXILISHE, D.S. 1987. Oral proficiency inXhosa as a second language.(D.Litt.) Promoters: J.J. Botha and J.A. du Plessis (207 pages).

\section{8}

VORSTER, D.J. 1988. Afstandsonderrig in Xhosa. (D.Litt.) Promoters: BOTHA, J.J. en DU PLESSIS, J.A. (200 bladsye) 